\title{
Edward Said's Worldliness, Amateurism and Heterotopia: Negotiating the Interdisciplinarity of Literary Theory, Canonicity, and Paradigm
}

\author{
Ayman Abu-Shomar \\ English Department, Faculty of Languages and Translation \\ Imam Muhammad Ibn Saud Islamic University, Saudi Arabia \\ E-mail: a.m.abushomar@hotmail.co.uk
}

Doi:10.7575/aiac.alls.v.7n.3p.136

Received: 18/01/2016

URL: http://dx.doi.org/10.7575/aiac.alls.v.7n.3p.136

Accepted: 14/03/2016

\begin{abstract}
Literary criticism nowadays is essentially crossing the boundaries of disciplinarity and canonicity where literary theory has increasingly been shaped by overlapping concepts and branching out of theories as well as whipping out the limitations imposed by theory itself. The post-conditions of contemporaneity have imposed a view of reading and analysing the literary text that is dynamic, proliferated and in flux as well as resistant to monolithic critique and confined disciplines and professionalization. This outlook has increasingly made the notions of literary criticism, theoretical paradigms and canons not only artificial and irrelevant to our materialistic world, but, in many cases, 'violent' to those whose life concerns exist in the margins of these paradigmatic notions. In this essay, I argue that those of us who aspire to an interdisciplinary and a metacritical analyses would be well served by importing inspirations from Edward Said's work, scholarship and life, particularly drawing on his 'Worldliness', 'Amateurism' and 'Heteroglossia' (or heterotopia) as well as drawing examples from his negotiation with intellectual paradoxes and tensions informed by his positionality as a border crosser intellectual (or his exilic consciousness). Specifically, this article engages with Said as an author of a radically secular body of work marked by as comportment towards being, and as an example of an "amateur" critic who "speak[s] truth to power". It argues that Said instates a critically-interrogative scholarship as antidote to essentialist, politicised, determinist and hegemonic literary canons (whether those of texts or theory) which are paradigmatically informed by relations of power in academia. The paper argues that through the investment of his scholarship and personal life, Said rejects academic institutions and affiliations with their tendency towards doctrinaire assumptions of critical work. Further to this, Said's fascination of diversity, heterogeneity and his advocacy of the intellectual's detachment from the institution of specialised criticism mount up as a radical critique of specialisation and professionalism and denouncing them as being allied with ideological and cultural dogma.
\end{abstract}

Keywords: Edward Said, worldliness, amateurism, heterotopia, inter/post-disciplinary literary theory

\section{Introduction}

The tradition of literary criticism has travelled some distance over more than a quarter-century since Antony Easthope's book Literary into Cultural Studies (1991), announced the fall of the literary theory paradigm. Since then, the realisation and usage of the literary theory has proliferated in several directions, and in several cases exceeding the limits of the concept to aggregate confusions which turn the issue of identifying the dividing lines between scholarly academic work and the obliviousness of academic disciplines. Easthope's work could be optimised as a foundational analysis to the crisis in the literary theory and paradigm. Easthope argues that with the passage of time, new evidence or contradictions within a paradigm accumulate and these contradictions continue to accumulate until the paradigm falls into doubt. Then, a crisis arises, a new paradigm emerges, and old theoretical questions are deserted. "Paradigms govern both theory and practice; they are both an entire constellation of beliefs, and the concrete puzzle-solutions that took place with them" (Kuhn, quoted in Easthope, 1991, p. 3). Easthope (1991) contends that literary theory has passed a similar status. Although the status of literary criticism once rested on a seemingly unchallenged foundation, the last decades of the twentieth century has disturbed these foundations. Reviewing the development of literary studies, Easthope contends that the old paradigm of English literary studies has collapsed. Within a period of two generations, "modern literary study was invented, institutionalised in the academy, fell into crisis, and is now being transformed into something else; cultural studies ... the moment of crisis symptomatically registered in concern with theory is now passing, and that a fresh paradigm has emerged, its status as such proven because we can more or less agree on its terms and use them" (p. 5).

To the heart of this argument is the seminal works of Edward Said whose scholarship cannot be reduced to any single discipline, and a scholar who has questioned and destabilises what seems to be coherent paradigm of literary theory. Said has established his scholarship in the borders of disciplines where these borders are stretched out and his scholarly influence is far-ranging and goes in several directions. His work has created space for scholars to analyse the discursive 
production of structures of authority, particularly in the imperial context, as well as to reflect on the implication of academic work in such production. In decades that have followed, regardless of their distance from Said's methodology or politics, scholars across multiple literary and non-literary disciplines have continued to engage with his work (Duvall and Varadarajan, 2007). Said's constant dialogic approach of 'exilic consciousness', for example, crosses the traditional borders of disciplines and have now become an established academic fashion of interdisciplinary intellectual and academic work. He concerned himself to establish an intervening in the constitution of reality, even when this proceeds from a primary engagement with literary texts within the context of the real world.

Postcolonial literary criticism and studies, in general, cannot be thought of without the phenomenal contributions of Said, as a matter of fact, Said is perceived as among the foremost pillars of postcolonial studies in addition to Homi Bhabha and Gayarti Spivak who are also received as theorists of crossing the boundaries of literary theory. In a sense, postcolonialism is taken up as an advanced and exceptional example of the interdisciplinarity of literary and cultural studies. Postcolonialism, according to Young (2001), "was never just an idea, a theoretical position, a philosophical view of the world; its ideas were embedded as part of a dynamic input into material political and social organisational infrastructures" (p. 427). Elsewhere, Young (2003) reasons that:

Post-colonial theory, so called, is not in fact a theory in the scientific sense [...]. It comprises instead a related set of perspectives, which are juxtaposed against one another, on occasion contradictory. ... Above all, postcolonialism seeks to intervene, to force its alternative knowledges into the power structures of the west as well as the way they behave, to produce a more just and equitable relation between the different people of the world (p. 67).

Considering the discursive nature of postcolonial literary criticism, Said could be taken up as the truest example of the postcolonial anguish voice for resisting marginality and periphery of the other. Said himself is the condition of 'postcoloniality' locating himself as an assortment of struggles to transcend the effects of colonialism through an engaged and situated intellectual practice. In his argument of the discursive nature of the 'theory', Quayson (1998) articulates the essence of postcolonial studies as interdisciplinary approaches directed to the hierarchical cultural and racial assumptions of European thought as well as responding to the dynamic and proliferated nature of the post-conditions of the global relations: "The Igbos have a saying that when the world is dancing, it is impossible to see it in perspective by standing still; and it is often argued that postcolonial critiques must move across boundaries in order to understand the complex relations secreted during the processes of colonialism and in its aftermath" (p. 76).

In the interdisciplinary terrain of postcolonial literary and cultural studies and criticism, Said established himself as an author of a radically secular body of work marked by as comportment towards being, and as an example of an "amateur" critic who "speak[s] truth to power" (Said, 1994). Speaking truth to power is considered Said's penultimate mission where he considers the basic question for the intellectual to admit their connection with their political realities, institutional affiliations, and restrictions intellectual specialisation (I will return to this argument below). Said has also developed a sense of an advanced and productive 'exilic consciousness' when living in the crossing borders of cultures. His sense of 'not-belonging' has confirmed his own sense that the public needs to speak from the margin, to distance him/herself from the orthodox opinion and say things which are denied those locked into partisan and specialist discourses.

My aim in this essay is to explore part of Said's work within the perspective of interdisciplinarity of literary theory and suggest that his scholarship and personal life address to the core of the idea of what might be referred to as 'anti/postinterdisciplinarity' in literary theory, canon and paradigm. I argue that Said instates a critically-interrogative epistemology as antidote to essentialist, politicised, determinist and hegemonic approaches to literary criticism and meaning-making, which are paradigmatically informed by colonialist assumptions. In so doing, Said both connects and alienates himself from the genealogy of Western literary criticism and thought; much of his writing discusses major European intellectuals, writers and philosophers, a fact that indisputably locates him in the canon of Western thought and philosophy, hence Western epistemology. Yet, Said's work is received as a forceful contrivance and an edifying humanising endeavour that is "free from the service of any God" (Said, 1994), and an intent of saying what can be said in a world that inhabit silence and an inability of articulation of those beyond the powerful 'centre'. I argue that Said's scholarship constitutes an inspirational spaces and expanding outlooks to stretch out literary criticsm beyond the confines of Eurocentric philosophical canon, which has been contested as a panacea of the monolithic, hegemonic, stereotypical and ideologically and politically constructed knowledge. As Massad (2004) argues, Said's role as anthropologist of Europe, its cultures, arts and literature excavates Western epistemology from its own interiority to externalise it outside Europe. Holding himself accountable to the very people and cultures he studied and wrote about, and engaging a partial reversal of European ontological authority, Said managed to do more than any other intellectual to unravel the archaeology of Western identity.

I also discuss that Said's critical stance espouses an anti-essentialist, anti-nationalist, a hermeneutic of 'worldliness', identity-less, anti-disciplinary as well as a non-affiliated spirit of morally situated secular criticism, or in Said's words, a 'non-Palestinian Palestinian' (Said, 1996). In short, Said could be read as an outstanding example of an intellectual who embodies a peripheral diasporic vision of reality that resists culturally and politically informed literary work. His scholarship, I contend, ingeniously touches upon the issues of literary criticism, affiliations, canonical paradigmatic assumptions and disciplinary knowledge and meaning-making, - all informed by Western and Eurocentric monolithic and hegemonic discourses and 'knowledge-making' traditions. The implicit aim of this essay is an attempt to put forward a contrasting reading between the 'violence' and hegemony of Western literary theory and affiliations, 
especially when directed to construct knowledge of the other, and Said's stance of anti/post-Western as one of dissent and resistance to the former.

In the coming sections of this essay, I discuss three of Said's major contributions that have extended literary theory: namely 'worldliness', 'amateurism', 'heteroglossia' (or heterotopia), and secular criticism as well as taking hold in his personal life construed in his 'exilic consciousness' or as an intellectual of continual border crossings. I contend that Said's scholarship comprises an advanced approach to the non-affiliated literary criticism; his entire critical academic identity and scholarship could be encompassed as follows: a) his concept of secular criticism, by which he means a criticism freed from the restrictions of intellectual specialisation; b) his advocacy of what he calls amateurism in intellectual life, a need for the intellectual's actual or metaphoric exile from 'home'; and c) his passionate view for the need for intellectual work to recover its connections with the political realities of the society in which it occurs. This connection with political realities enables the intellectual to speak truth to power, and the relationship of criticism to the world's materialism (or worldliness), which is discursively constructed. Drawing on these repertoires, I argue that Said has, more than anyone else has put forward inspirational spaces and expanding outlooks to stretch out literary criticism beyond the confines of Eurocentric canon, which has been contested as a locale of the relations of power in academia.

The Worldliness of the text and the critic

No other theorist like Said has powerfully revealed how 'down to earth' theory really is, for it comes to being in some place, for particular reason, and with particular history. For whether he is talking about English literature, about the complexities of texts and how they are formed, about the ways in which the West exerted power over the Oriental world, about the functions of intellectuals in society, or even about music, his own place as an exiled Palestinian intellectual has inflected his work. In his study of the literary text, Said insists on the worldliness of the text by viewing and interpreting the text as something that originates in the world, the basis of its being. The most significant aspect of his cultural analysis is that while post-structuralism dominates the Western intellectual scene, he adhered to a determined and unfashionable view of the ways in which the text is located materially in the world. Bridge (2006) argues that literary theory is perceived as not lending itself to addressing problems in the real world behind the text: "the more firmly established a theory is the less explicit is people's awareness of its rules. It is in the formation and development of new patterns of enquiry that people are especially aware of what is distinctive about it" (p. 265-6).

Said's worldliness provides an outlook to understand the role of the intellectual in contemporary society and the function of literary criticism. For him, the concept underpins the broad-ranging motifs that have occupied his career, and a view of the world inextricably intertwined with academic work; for Said, it is indeed that 'human history is made up by human beings' (1983). He perceives the problem with contemporary intellectuals, and critics, in particular, is their extreme attention to the employment of specific theories with far too little attention given to its materiality. Said charges critics for taking the text as "a kind of self-consuming artefact; idealised, essentialised, instead of remaining the special kind of cultural object it is with a causation, persistence, durability and social presence quite its own" (1983, p. 148). To him, the materiality of the text refers to various things: the ways in which the text is a monument, a cultural object sought after, fought for, possessed, rejected, or achieved in time. Textual materiality, according to Said, includes the range of its authority as well as the writer's own position in the world; it is constructed out of many available discourses within which the writers could be seen as subjects in process. Ultimately, worldliness is concerned with the text's origin, for this material being is embedded in the very materiality of the matters of which it speaks: dispassion, injustice, marginality, and subjection.

To understand Said's worldliness as a theoretical stance that is interrogative, responding and in always in flux, it is important to consider structuralism and post-structuralism as prevailing theories of the age. Structuralists see texts as structures constructed from elements available in the social and cultural 'paradigm', which makes its 'final' meaning, and post-structuralists, on the other extreme, accept the constructedness of texts denying that a structure could ever arrive at a final meaning; it is always deferred along endless chain of signifiers. Although both theories are appealing to generations of conflicting thoughts, Said, coming from a worldly position, rejects both theories pointing out how unsatisfactory the whole idea of textuality and of endlessly deferred meanings is. He points out that in order to treat meanings as limited to the textual internal structure is to miss the important fact that the text is an 'act' located in the world, and to treat the text as merely a structure of the paradigmatic and syntagmatic is to 'divorce' the text from its worldliness; its cultural production, cultural act and the relations of power within which it is produced. When the text is located in the world, it extends beyond the material presence of the script to the link between academic textual practice and its location in the matrix of power relations; its material presence in the world; its cultural and social history; its historical contingency; its circumstantiality; its political and economic being as well as its connection with other texts and the material world behind these texts.

Said further argues that texts in the world have various kinds of affiliation with the world, and one of their functions is to solicit the world's attention, and in this manner texts announce their worldliness without simply reflecting it, and without assuming that the author is some kind of 'centre' of meaning. Texts for him are fundamentally facts of power, not of democratic exchange having a relationship; similar to that between coloniser and colonised, oppressor and oppressed. It is precisely from this situation of unequal discursive relations that Orientalism as a scholarly discipline emerged (Said, 1983). It is this power relation introduced by the academy of European power throughout the nineteenth century and a recapitulation of the political and racial exclusions instituted by that dominance. In short, Said, insists that there is no other power relationship describes so forcefully like the relationship between the text and the world. This 
relationship makes untenable the principle that texts are spate form the world including, too many historical, ideological and formal circumstances, all of which implicate the text in actuality.

But what are we to make of this? How this critical stance is relevant to the postdisciplinary literary theory? How does this position mount up as antidote to canonicity and affiliation? In response, Said argues that the crucial characteristics of the texts is that of 'filiation' (heritages or decent) and 'affiliation' (narrow view of specialisation) while, at times, the term 'filiation' was deemed as a coherent force in the traditional society, it has become increasingly difficult to maintain such a tradition in the complexity of contemporary civilisation and, therefore has been replaced by the term 'affiliation', a process of identification through culture. Said sees the text as a phenomenon in the world, located in a net-work of non-literary and non-traditional affiliations, on other words, a transdisciplinary web of knowledge. Said brought to questions the modernist professionalism labelled as theories since the serve dominating interests, at best, the 'lust' of aesthetic maintained by 'academic bourgeois', at worst. In this sense, the act of reading is freed from the narrow confines of affiliative canonical or disciplinary professionalisms. Within this understanding, Said, defines the concept of affiliation as referring to "that implicit network of peculiarly cultural associations between forms, statements and other aesthetic elaborations on the one hand, on the other, institutions, agencies, classes, and amorphous social forces" (1993, p. 174). In a crossing-to-boundaries step, Said locates affiliation within the realm of Gramscis' hegemony (or controlling people against their interest but with their consent), and suggests that the affiliative network itself is the field of operation of hegemonic control, especially the control of the imperial culture.

Drawing on the above argument, it can be elicited that Said's arguments regarding the worldliness of the text touches substantial issues of disciplinarity and affiliation, and deems the tradition of adopting monolithic approach to the text (e.g. intertextuality or the text as a separate meaningful entity) a 'violent' task in the part of critics, is often set out to misrepresent the 'other'. The argument is that theoretical paradigms or affiliations and professionalisation entail 'violence' since the scientific community that is organised around a paradigm, believing in making that paradigm a 'conceptual framework', 'a way of seeing things' makes the adopted paradigm a pejorative concept for the dominant mode of seeing and understanding the world, and a 'code word of meaning'. Derrida (1974) insists that such violence must be seen as violence since every paradigm is a fiction, a contingency, and a "way of laying things out which cannot claim absolute status or immunity from reform" (p. 217). Drawing on this, the dominating nature of paradigm overlooks the discursive and context-bounded nature of meaning-making, and, does not only marginalise the voices of 'others', but also, in many cases, provides less effective solutions beyond what conceptual 'frameworks' could offer. Heidegger, Kuhn, and Derrida (as cited in Caputo, 1987 p. 220) view paradigms as being structured around 'subversiveness' and 'normalcy', or "only a certain contingent arrangement of signs whose efficaciousness is responsible for its success but which is so marked by contingency that it is always vulnerable to subversion" (p. 86).

In a similar manner, Griffith and Miler (2008) charge disciplines as limiting in the quest for 'truth'; analogous to Said's argument regarding textual limitations. They contend that "the focusing of the group's attention on a single series of phenomena [or the text as a self-contained and edifying world] and the development of a distinctive scientific style [structuralism or post-structuralism] results in a considerable restriction of information regarded as relevant [a view of meaning of the sign residing in its difference from other sign (structuralism), or endlessly deferred meanings (poststructuralism)]" (p. 46). Said's worldly approach to the text and his rejection of affiliation interrupts the universality of Western canonical theories (e.g. structuralism and post-culturalism), and destabilises the core of the literary theory paradigm in its search for truth and knowledge-making. When this argument is contextualised in a world that is governed by relations of power whether during the Orientalist and colonialist eras or in our contemporaneity of postmodernism, post-conditions, globalisation and neo-colonialism, - Said's line of thought can be assumed as an advanced genre of critical position that favours anti/post-disciplinary literary theory.

Furthermore, for Said, the stance of worldliness, or worldly criticism, does not stop in the sphere of the text, but also addresses that of the 'critic', the professional, the scholar and the affiliated intellectual. The argument is that Said's worldly criticism refutes the increasing professionalization of literary criticism where theory could only be talked about in the most complex language and within a small circle of critic intellectuals. The key idea of Said's worldliness of the intellectuals is their capacity to say anything relevant to their world since their intellectual production cannot be dispensed from the real world they live in. This world, for Said, is inevitably a source of considerable paradox, yet, there is no question that this world is crucial to the perception of the value of the intellectual work. Within this understanding of the intellectual worldliness, Said's argument is a radical attack on the creeping ivory-tower specialisation which has come to characterise literary criticism, which removes the task of literary analysis more and more from the worldly, social, cultural, political and economic realities of contemporary society. It is therefore my contention to claim that Said's world comprises an advanced and radical example of metacriticism, post/antidisciplinarity of literary analytical work. In this sense, professionalization and commitment to the boundaries of the theory would 'socialise' intellectuals into their affiliated specialisations where they fail to notice the 'gaps' and discontinuities that their adopted theories fail to see (Bridge 2006). Indeed, through 'normalisation' of the concepts and rules of the adopted and affiliated theory scholars miss the chance to examine the 'shifts', 'developments' and 'omissions' that their pleas for coherence and focus on methods, theories would marginalise those ideas which fall on the margins of these theories (Ninnes and Burnett 2003). It could be concluded, that in Said's meta-narrative critical approach of worldliness and affiliation is an emancipatory projects that is set out to 'problematise systems' calling for radical shifts from the modernist certainties and essentialist views of reality to non-essentialist post-modernist destabilisations which view reality as multiple and constantly changing. In a 'postdisciplinary world', the course of metaphors of knowledge has thus shifted from static logic of a foundation and a structure to the dynamic properties of a 
network, a web and flied where the critic is located in an amalgam of diverse and warring thoughts (Klein, 2000). After Kuhn, Caputo contends: "the most creative moments in the history of science occur precisely when scientific stereotypes loosen - in times of crisis, anomaly, of human idiosyncrasy, error and confusion” (p.119).

In sum, master narratives of literary theory have been often trapped by limitations and commitments imposed by the theory itself when particular theoretical frameworks often fail to perceive the discursive nature literary analytical work, and thus provide inadequate responses to the dilemmas and tensions entailed in the text. After Said, Rivas (2005) argues that literary criticism has not only been established in the academy with its fields of respective meanings, but also 'institutionalised' in governments, industries, and special interests groups. Embedded in cultural practices, Western literary theory is implicit in social constructions, which are based on modernist/Enlightenment ideologies that are historically specific (modernism) and culturally distinct (the West). As Haraway (1988) puts it, "the humanist and modernist notions, bearing Western genealogy, and favouring the notion of paradigm, bear a parochial nature with their howling exclusions and swaths of disattended scholarship" (p. 25).

\section{Amateurism; the spirit of secularism}

Related to his notion of worldliness, whether that of the text or that of the critic, is Said's advanced and throughout argument of secular criticism, which also informative of his anti-disciplinary and paradigmatic stance. For him, the academy speaks to itself rather to the world of everyday life and ordinary need, and therefore, he advocates secular work, which contests at every point the confined specialisations of critical work and discourse. Said perceives the real problem with critics' ability to make difference in the world is their trap in specialisation. His idea of amateurism is therefore an answer to the intellectual trap of specialisation, a 'cult of professional expertise', as he calls it (Said, 1993), which has made their work marginal to the demands of post-condition of contemporaneity. Said argues that specialisation projects scholars as privileged over the real world, and as imperialistic towards other viewpoints and adopting the canonical knowledge of the 'centre' taken for granted, a tradition that alienates any knowledge coming from the 'periphery'. In response, he proposes a radical view of secularism by drawing on a simple, but compelling idea of 'amateur' scholar. For him, 'amateurism' dispenses with 'priestly' and abstruse specialisation in favour of an interest in worldly matters which it occurs in. No matter how much intellectuals may believe that their interests are of 'higher things or ultimate values', the morality of the intellectual's practice begins with its location in the secular world, and is affected by "where it takes place, whose interests it serves, how it jibes with a consistent and universalist ethic, how it discriminates between power and justice, what it reveals of one's choices and priorities" (1994, p. 89). In his attack to discipline and specialisation Said writes:

We have reached a stage at which specialisation and professionalization, allied with cultural dogma, barely sublimed ethnocentrism and nationalism, as well as a surprisingly insistent quasi-religious quietism, have transported the professional and academic critic of literature - the most focused and intensely trained interpreter of texts produced by the culture - into another world altogether. In that relatively untroubled and secluded world there seems modern history, intellectuals and critics have intact built (1983, p. 25).

Said contends that contemporary critical work is characterised more and more with narrowly focused specialisation to which secular criticism is adamantly opposed. He understands that the alternative to such specialisation is an amateurish secular critical work that rejects dogma: "in its suspicion to totalising concepts, in its discontent with reified objects, in its impatience with guilds, special interests, imperialised fiefdoms, and orthodox habits of mind" (p. 29).

Indeed, Said has strikingly touched an inextricably intertwined, knotted and uninterrupted line of thought starting with worldliness to secularism, and to achieve this continuation, he introduces the disarming, not to say disconcerting, idea of the intellectual as an 'amateur'. He insists that a critic must refuse to be locked into narrow professional specialisation which produces their own arcane vocabulary and speak only to other specialists (Said, 1983). The magnitude of Said's 'worldliness' is extensively intense and abyssal where his amateurism stands as a reversal to the monolith of the hegemony of professionalization and the Western canon, yet, not is a superficial dilettantism, but rather when questions of justice, oppression, marginalisation are at stake. He charges theory, with its Western lineage as locking the intellectuals into an in-worldly spiralling discourse and concepts on accessible to other similar professionals (Said, 1996). Certainly, the word 'amateur' is informative one, since its pejorative connotations disrupt our sense of the function that the critic fills in contemporary society. When he is asked about the reason of using the term amateur rather than 'generalist', Said answered that the literal meaning of the French word is highly connotative meaning 'the love of something' and "very involved in something without being professional" (Ashcroft, 1996, p. 8). For Said, the amateur is one who believes that to be a thinking and concerned member of society one can raise moral questions about any issues, no matter how technical or professional the activity (1993, p. 61). According to Said, the province of the critic amateur includes multitude of activities including literary theory, textual criticism, history, discursive analysis, sociology, musicology, anthropology, and, above all, the politics of cultural difference. In one of his lectures on $22^{\text {nd }}$ of July, 1993 , Said maintains:

I spoke about the way an intellectual can become a professional who specialised in one bit of turf, accredited, careful, speaking not the general language of a wide audience but rather the approved jargon of a group of insiders. As an alternative, I suggested that as a way of maintaining relative intellectual independence, having the attitude of an amateur instead of a professional is a better course. But let me be practical and personal here. In the end, one is moved by causes and ideas that one can actually choose to support because they conform to values and 
principles one believes in. I do not therefore consider myself bound by my professional training in literature, consequently ruling myself out from matters of public policy just because I am only certified to teach modern literature. I speak and write about broader matters because, as a rank amateur, I am spurred on by commitments that go well beyond my narrow professional career. Of course, I make a conscious effort to acquire a new and wider audience for these views, which I never present inside a classroom.

In this extract coming from one of his lengthy lectures, Said addresses intellectuals, or, in fact, trains them into understanding and reporting the world, not from the perspective of a professional who is doing duty, but rather from a passionate amateur who is really concerned of truth and the owners of this truth. In line with this argument, literary critics should abandon taking up the epistemological stance to be paradigmatically and theoretically bounded, but as amateurs who strive to make an ethical disclosure and conduct, or, in Pierre's (2000) words, "an investigation of where our search for meaning goes and what it does there" (p. 27). This is similar to Kuhn's analogy of someone "new to the profession'. By "being little committed by prior practice to the traditional rules of normal science, [she/he is] particularly likely to see that those rules no longer define a playable game and to conceive another set that can replace them" (quoted in Caputo, p. 220). Lather describes this state of an intellectual as 'rigorous confusion' that proceeds in fits and starts, and makes no claims of mastery, which involves willingness to persistently critique 'what one cannot not want'. In a similar vein, Spivak calls this approach a "philosophy in which we feel freest" (quoted in Pierre, 2000, p. 27).

In short, I understand Said's amateurism as an ethical critical stance beyond the confines of professionalization and canonised apparatuses of literary theory, yet, it is actively engaging with concrete and worldly matters including its cultural, social, political, ethical, and material endeavours. I deem the value of Said's worldliness and amateurism an informed approach that does not stray from the lived experiences of people whether inside or outside the text. To this end, after Pierre (2000), I read Said as a scholar whose comportment and responsibility is to keep the stance of meaning-making and interpreting human lives in play, increasingly unintelligible to itself, in order to produce different knowledge and produce knowledge differently as amateur scholars work for social justice. To take this argument a little bit further, I deem Said's critical stance as a genre of "critical post/anti-disciplinary literary studies" that seeks to "expose how relations of power and inequality, (social, cultural, economic), in their myriad forms combinations, and complexities, are manifest and are challenged in the critical work.

\section{Said's exilic consciousness; a border-crosser scholar}

As much as his scholarship is informed by a disposition to worldly and secular criticism, Said's living conditions, or what he prefers to call, his 'exilic consciousness' provides another informed stance of anti-paradigmatic literary criticism. Although intellectuals' personal life could not be necessary to the direction of their theories, and even speaking of their lives could be 'scandalous' to some theorists, the case is different for Said (Ashcroft and Ahluwalia, 2002). Said embodies an exceptional endowment through which he negotiates with his liminal, hybrid and exilic identity that enables him to provide axiomatic directives towards envisioning alternative realties beyond the Western epistemological canon. In other words, I argue that while identity questions bring about strivings and crises to people of Diaspora, Said fosters his diasporic case into a 'productive crisis' (Souza, 2009). He tactfully and conscientiously consummates his 'exilic consciousness' through negotiating with paradoxes and contradictions to accomplish a unified critical epistemological stance. His struggles with dislocation and realisation of the potential of exile are endeavoured to radically secularising his comportment towards being and farsightedness. The trajectory of Said's diaspora enables a vista to disrupt the "imperial discourse of the West and to weave his cultural analysis with the text of his own identity" (Ashcroft and Ahluwalia, 2002, p, 4). That is, through conscious attentiveness to the challenge of being critical, Said accentuates the tensions and constant struggles involved in the crafting of a politically and critically engaged intellectual and personal life.

Said's scholarship and critiques have been consistent and have emerged from his sense of his exilic condition, a state of being and existence that qualifies a diasporic and disinterested scholarship. Although this claim sounds eccentric, especially with writings that have banqueted over academia considering Said's theories as ideologically-laden critiques, I understand Said's project as bearing a corrective case of the canonical representation of history vis-à-vis his diasporic negotiations with contradictions. Through his embodiment of the sense of 'not-belonging', border-crosser and 'amateurism', Said provides a subtle stance of secular humanism: a thesis explicitly articulated in his own words, to 'speak truth to power' (1994). I realise Said's scholarship a project that is fused from an impetus of diaspora, exile and a productive consciousness, as well as a corrective and edifying project of European Humanism that is grounded in doctrines and prejudices of thought informed by various and myriad lineages of ideologies.

Adorno insists that "there is no cultural document that was not a manifestation of barbarism" (as cited in Gur-Ze'ev, 2005, p, 14). Establishing himself as a scholar-in-exile, as a milieu and a locus of enunciating his epistemology, Said comprehends and incorporates this theme, hence, he perceives the endeavour of approaching 'truth' via ideology and culturally informed epistemology is problematic. Through his theories of cultural representations, in particular, Said provides an example of splendid diaspora by directing his criticism the 'politics of cultural texts' (Said, 1983). He however fulfils this aim not as being victimised by the fetishism of one's subject position, but rather through challenging nihilism in all its forms, yet, insisting on love and intimacy where human rationality cannot be enslaved by an authentic 'I'. Consummating an 'in-between' locale, Said figures out that for an examination of cultural texts, the author as a locus of power must be examined (ibid), and when paradoxes and contradictions are involved, they must be 
navigated and negotiated (Said, 1994c). Imbibing an exilic and hybrid identity and favouring secular criticism bear great capacity to disrupt cultural assumptions as social and political injustice. As Massad (2004) explicitly puts it: "he [Said] insisted on being politically godless in an age dominated by the worship of political deities - the "West", Soviet communism, U.S. imperialism, nationalisms of all varieties, to name the most prominent" (p, 7). Detaching himself from the partisan politics and confines of institutionalised knowledge, Said exemplifies a stance of human ontological diasporic existence, as a venture that unbinds the mind from the monolith of the self and the other that makes diaspora an impetus to new possibilities for meaning which rejects being at 'home' at all costs. Said consciously establishes himself 'between worlds', or what he calls 'interstitial spaces' (Said, 2000); spaces of complex, constant and constitutive manifestation of Diaspora. He figures out a diasporic epistemology as labyrinthine in nature including discursively constructed and mobilised identities that rejects the notion of the monument of the belonging. Its multifaceted manifestations, narratives and dialogic engagements are vibrantly located in-between spaces that diffuse confluence and convergence of multiple ideas, meanings, cultures, experiences, which offers myriad sites of contestation to the hegemonic and homogenising forces. Indeed, Said is anxious of locations, and his 'obsession' of cultural diversity and heterogeneity embodies his critical demeanours through his fragmented identity, which renders the multiplicity, mobility and dynamicity of epistemologies not only conceivable but also inevitable.

The diasporic epistemology of Said could also be realised through his rejection of a 'confined specialisation' as it is connected to other aspects of the world such as political, social and cultural. Duvall and Varadarajan (2007) argue that Said was committed to a model of interpretation that was attentive to the broad institutional structures and socially diffuse systems of signification of 'the normal', 'the privileged', and 'the ideal', - consequential accounts rooted in the action of specific identifiable actors. Said frees his criticism from restrictions of intellectual specialisation through his advocacy of an actual or metaphoric exile from 'home'. To him, an intellectual should be that of migrant and exile in the sense that they should critically engage with the accepted truths or wisdoms of one's community by being culturally and politically atheists (Said, 1994c). Closure for Said comes through one's commitment of "the public mood for reason and solidarity, primordial loyalty, or national patriotism" (1996, p, 32).

Nonetheless, diaspora entails an amalgamation of convictions including an individual's dispersion; uncanniness (e.g. memories, myths, alienation); ongoing and hybrid identities; complex histories of dwelling; or in Clifford's words (1997), 'dwelling-in-travel' - all of which embody predicaments, yet, an interrogative case to the rubrics culturally informed or 'affiliated' epistemologies. Mishra (2007) insists that "diasporas are people who would want to explore the meaning of the hyphen, but perhaps not press the hyphen too far that this would leads to massive communal schizophrenia" $(\mathrm{p}, 13)$. Perhaps this state could apply to Said's diasporic epistemology, as entailing antagonism, dilemma, and 'uncanniness', but not as causing impasse, 'negative utopia' or being enslaved by victimisation or human suffering. The agony of 'dislocation and disposition' however remains an active demeanour for Said; he is often seen as being trapped between his exilic consciousness and his political concerns, especially those of the Palestinian case. That is, given Said's emphasis on maintaining an exilic attitude in parallel to his passionate advocacy of specific political struggle. Among several other tensions, Ashcroft and Ahluwalia (2002) see Said as "a person located in a tangle of cultural and theoretical constrictions ... between his Westernised persona and hid political concern for his Palestinian homeland ...; his political voice and professional position; ... [and] between the different ways in which he has been read" (p, 5). 'Uncanniness' (Bhabha, 1994), for Said, becomes an interpretive mode to deal with the juxtapositions of memories. His diasporic knowledge constantly oscillates between the axioms of dissent and repulsion as his condition of exile is merged in the jubilant memories of the past to create a combination of 'time lag' and constant formation of his identity. Probably the best about Said's scholarship, hence, epistemology is the manner he confronts paradoxes and contradictions emanated from his diasporic stance. For him, diaspora is an ontological, epistemological, existential attunement that immune him from being swallowed by the arsenal of politics, nationalism, and the confines of scholarship.

As for our current argument of post/anti-disciplinarity, Said's exilic consciousness and border crossing are to be fostered as radical locale against cultural as well as institutional affiliations. To perceive Said a crossing-border intellectual, it is important to define the predicament of the border itself. "How can one situate oneself of the border? What kind of space characterises it?" JanMohamed asks (1992, p. 225). In response, JanMohamed argues that "borderers are neither inside nor outside the territory they define but simply designate the difference between the two ... they are points of infinite regression" (p. 73), and intellectuals located as border-crossing are forced to constitute themselves as the border.

Prior to developing an understanding of how Said's diasporic identity is informative of anti-disciplinary literary criticism, it might be helpful to tackle the concepts of 'institution' and 'society'. While society is taken to be the wider arena that shelters the institution and determines its existence, institutions, are the active agents that own the volition of what the society should or should not include (Fowler, 1999). The institutionalisation of literary criticism has been looked at as a forceful tool to maintain relation of power and passing off traditions and ideologies while ding critical work. Here, I find it useful to expand the concept of the institution to include any agents involved in the 'profession' including large academic networks whose members regulate the complex process of classifying, valuing, and disseminating knowledge (Graft, 1987). Institutionalisation becomes a collective body of associations that constitute the academic system in which each institution influences the way knowledge is viewed, produced and disseminated, and therefore performs a social function as gatekeepers between knowledge and its audience (Westhuizen, 2004). This network includes many actors, e.g. reviewers, publishers, prize committees, and other agents within political, economic, and artistic subsystems of society whose roles are profoundly influential in determining the boundaries of each 
discipline. Related to this broad notion of institution is the idea that meaning-making (or literary analysis and textual interpretations) is a form of social and cultural action referring to a certain group's ideology that shapes all cultural productions of that group, and/or an individual's ideology that is shaped by the prescribed boundaries of the dominant discourse of the society (Bourdieu, 1984). Yet, it is important to notice that any form social action exercises its power in unstable sites of ideological contestations, and in discursive ways that are shaped by different socio-political and cultural contexts. Drawing on this, the idea of institutionalisation, 'professionalization' or 'academicisation' of literary criticism affiliates with the notions of paradigm, canon, and literary theory is no exception.

Both Said's life and scholarship provoke serious thought about the border as site of intellectual work, thus, projecting an advanced example of deconstructing literary theory in its strict sense. Borders for Said, are locales for articulation epistemic and socio-political differences; borders become analogue differences that are highly valorised and formulaic punctuations of infinite and continuous and heterotopic differences (JanMohamed, 1992). JanMohamed argues that "in socio-political register, borders that articulate or impose categorical 'differences' between groups - demarcated in terms of 'nations', 'cultures', 'classes', 'races', etc. - tend to reify analogue relations into imaginary identities and oppositions" (p. 235). In the case of border intellectuals, JanMohamed argues, the rupture aspiration or egoideal valorised by the dominant culture and the experience of actual social devaluation cuts through the very centre of subjectivity. This rupture is not inflicted on an already formed individual or subject but is involved in the very process of formation where the border subject becomes the site on which a group defines its identity.

This argument has profound implication in Said's case of border crossing as it informs the heterotopic of the intellectual. Drawing on Foucault's 'heterotopia', JaneMohamed argues that the intellectual border crosser develop two sites that "have the curious property of being in relation with all other sites, but such a way to suspect, neutralise, or write the set of relations that they happen to designate, mirror, or reflect" (Foucault, qtd in JanMohamed, p. 237). These two sites are linked with all others, but primarily by a relation of contradiction. For JanMohamed, heterotopias, like boundaries, established in the very founding of society, are counter-sites in which all other real sites that can be found within a culture are simultaneously represented, represented, contested and inverted: "while Foucault's heterotopic sites are all social and institutional spaces - cemeteries, fairs, libraries, prisons, etc. - the border intellectual is simultaneously a space and a subject, is, indeed, a subject-as-space" (p. 237) [emphasis original].

In its most radical instance, the stance of the border crosser intellectual has a profound agency and a desire to deconstruct the perceived 'Manichean' subjectivity - the duality of dividing things into good and bad - and becomes a prolonged project, which in turn constitutes the core around which a new subjectivity begins to coalesce. The transformation of the border subject emerges from the potential of their heterotopic site to actual heterotopic specular border intellectual by depending on their own agency which allows them to directly or indirectly reading himself or herself as heterotopic border intellectuals. In many ways the border intellectuals have no intention to produce a totalising theory, but embracing an intimate experience of boundaries, they espouse deconstructions. This condition of Said, in particular, suggests a way out of the dilemmas of dualisms in which intellectuals are often trapped in. This state, according to JanMohamed, mounts up of a powerful heteroglossia:

Said's valorisation of affiliation over filiation can be read as form of infidel heteroglossia. While the life of Joseph Conrad (with whose border crossing Said begins his professional career) also exemplifies a certain type of heteroglossia, Conrad's discomfort with and desire to overcome the dilemma of the border intellectual is marked by a dual desire: to belong to a selct group, to become and insider - one of us - as Marlow puts it in Lord Jim and to value fidelity above all else (p. 238).

Unlike, Conrad whose case as deemed as a process of identification and filiation, Said, as an intellectual border crosser, affirms the values of infidelity to cultures, nations, groups, institutions, etc., to extend that these are defined in monologist, essentialist terms. For Said's case, the task of the border crosser in the academy, the political phenomenology founded in his positionality necessarily leads him to profound ad radical shifts from Western canons, paradigms, institutional 'culture' and disciplines. For Said, whether in his own academic and personal life or in his scholarship, the case of border crosser and exilic consciousness has been a demeanour to place an upper hand on the politics of scholarship and professionalization as he invested his own life, with all its paradoxes, to one major aim: the ethical and moral stance of humanist scholar whose ultimate aim is to "speak truth to the powerful".

The investment of Said's border scholarship has projected enormous amount of theoretical work than has banqueted over academia. Scholars, whose works functions against the borders of Eurocentric and patriarchal cultural, academic and institutional canon, often find the inspiring work of Said a locale of emancipation from the relation of power dominating institutional and academic professionalization and specialisation. They have explored in diverse ways the power and limitations of the academic work especially when directed to resist the politics of the academy. The resistance of the notion of discipline called these intellectuals to produce a huge corpus of academic work based on the notions of heterotopic sites and the homelessness of the intellectual. Gayatri Spivak's "Third World" feminism, for example, can be located as a radical criticism to the Western feminist canon. Henry Giroux's "Critical Pedagogy", informed by the work of Said and others, urges both the educators and students to scrutinize knowledge from the position of border-crossers, as people moving in and out borders constructed around coordinates of difference and power. Critical Pedagogy encourages learners "to develop a relationship of non-identity with their own subject positions and the multiple cultural, political, and social codes that constitute established boundaries of power, dependency; and possibility" (Aronowitz and Giroux, 1991, p. 200). 


\section{Conclusion}

Indeed, pathways to reading Said are myriad, and discussions of his legacy can go in endless directions and from several perspectives. His emancipating scholarship has created unprecedented spaces for scholars to engage and analyse the discursive production of structures of authority, particularly in the imperial context and how to reflect on the implication of academic work in such production. His scholarship can readily be seen in far-ranging disciplines including literature, cultural studies, sociology, history, geography and anthropology, and epistemology (or the philosophy of knowledge) cannot be an exception. He is a 'rare breed of academic critics' dedicating so powerfully his academic and personal life to reveal how 'down to earth' theory really is.

Said's interrogative work questions the foundations of the ways Western knowledge has been constructed and mounted up as an example of universalist literary canon. Said's major contribution remains in his radical critique of academic professionalization and affiliation through directing attention to authorial power of the intellectual, and literary critic, in particular, that is embedded in culturally and institutionally informed assumptions. Said's intrusive method situates itself as antidote to the institutionalisation of the structures of knowledge or the systems of 'Orientalising the Orient', which draws on the forces of the knowledge power relations. Probably, Said's scholarship and academic edifice could be captured by the two phrases 'Worldliness-Without-World', 'Homelessness-as-Home' that underlies the authorial subject-position as moving across specular borders. Said's concerns with exile is, thus, a vibrant space for intellectuals who are located at the juncture of the world that forms them, and is transformed by their border-crossing into positive missions that lead to significant cultural acts. In brief, Said inaugurates a project of scholarship and the intellectual work that deconstructs and decolonises literary and cultural studies as affiliated disciplines. As the relationship between disciplines and paradigms is implicated by the institutional affiliations and the limitations of the specialisation, the multitude of Said's arguments including 'worldliness', 'amateurism', and the heterotopia of border crosser - are allencompassing concepts that delineate cross-disciplinary studies and the subject positions of the intellectual.

\section{References}

Aronowitz, A. and Giroux, H. (1991). Postmodern Education: Politics, Culture and Social Criticism: University of Minnesota Press, Minneapolis.

Ashcroft, B. (1996). Against the tide of time: Peter Carey's interpolation into history. Writing the Nation: Self and Country in the Post-Colonial Imagination, 194-213.

Ashcroft, B. and Ahluwalia, P. (2002). Edward Said. London: Routledge.

Bhabha, H. (1994). The location of culture. London: Routledge.

Bourdieu, P. (1983). The forms of capital. In Richardson, J. (Ed.), Handbook of Theory and Research for Sociology of Education. New York: Greenwood Press.

Bourdieu, P. (1984). Distinction: A social critique of the judgment of taste. Harvard: Harvard University Press.

Bridges, D. (2006). The disciplines and the discipline of educational research. Journal of Philosophy of Education, 40 (2), 259-272.

Clifford, J., (1997). 'Diasporas'. Cultural Anthropology, 9(3), 302-38.

Caputo, J. (1987). Radical hermeneutics: Repetition, Deconstruction, the Hermeneutic Project. Bloomington: University of Indiana Press.

Derrida, J. (1974). Of grammatology (G. Spivak, Trans.), Baltimore: John Hopkins University Press (original work published 1967).

Duvall, R., \& Varadarajan, L. (2007). Traveling in paradox: Edward said and critical international relations. Millennium-Journal of International Studies, 36(1), 83-99.

Foucault, M. (1980). Body/power. In Gordon, C. (Ed.), Power/Knowledge: Selected Interviews and Other Writings (1972-1977 by Michel Foucault (pp. 55-62). Hertfordshire: The Harvester Press.

Fowler, A. (1999). Civil society, NGDOs and social development: Changing the rules of the game. Geneva 2000 Occasional Paper, 1. UNRISD, Geneva.

Graft, G. (1987). Professing literature: An institutional history. London: The University of Chicago Press.

Griffith, B. C., \& Miller, A. J. (1970). Networks of informal communication among scientifically productive scientists. Communication among scientists and engineers, 125-4.

Gur-Ze've, I. (2005). Critical theory and critical pedagogy today: Toward a new critical language in education. Haifa: University of Haifa 31905.

JanMohamed, A. (1992). Worldliness-Without-World, Homelessness-as-Home: Toward a Definition of the Specular Border Intellectual. In Michael S. (Ed.), Edward Said: A Critical Reader. Oxford: Blackwell: 216-241.

Klein, J. T. (1990). Interdisciplinarity: History, Theory and Practice. Detroit: Wayne State University Press.

Klein, G. (2002). It Takes More Than a Passport: Interdisciplinarity in Study Abroad In Haynes, C. (ed.) Innovations in Interdisciplinary Teaching. Washington, DC: American Council on Education / Oryx Press, pp.201-220. 
Lather, P. (1991). Getting smart: Feminist research and pedagogy with/in the postmodern. New York: Routledge.

Massad, J. (2004). The intellectual life of Edward Said. Journal of Palestine Studies, 33(3).

Mishra, V., (1996). The diasporic imaginary and the Indian Diaspora, Asian Studies Institute, Victoria University of Wellington.

Ninnes, P. \& Burnett, G. (2003). Comparative education research: poststructuralist possibilities. Comparative Education, 39, 279-297.

St. Pierre, E. A. (2000). The call for intelligibility in postmodern educational research. Educational Researcher, 25-28.

Quayson, A. (1998). Means and Meanings: Methodological Issues in Africanist Interdisciplinary Research. History in Africa, 25, 307-318.

Rivas, A. (2005). Postcolonial analysis of educational research discourse: Creating (Mexican) American Children as the "Other". (PhD dissertation). Texas A \& M University.

Said, E. (1978). Orientalism. Harmondworth, London: Penguin.

Said, E. (1983). The world, the text, and the critic. Cambridge, Mass: Harvard University Press.

Said, E. (1993). Culture and imperialism. London: Chatto \& Windus.

Said, E. (1994) Representations of the Intellectual, the 1993 Reith Lectures, London: Vintage.

Said, E. (1996) Lost between war and peace: Edward Said travels with his son in Arafat's Palestine, London Review of Books, 5 September: 1014.

Said, E. (2000). Globalizing literary study. PMLA, 116, 64-68.

Souza, L. (2009). 'Editor's preface', critical literacy. Theories and Practices, 1, 4-5.

Young, R. (2001). Postcolonialism: A historical introduction. London: Blackwell.

Young, R. (2003). Postcolonialism: A very short introduction. Oxford: Oxford University Press.

Westhuizen, C. (2004). Judging the book. Journal for Language Teaching, 38, 144-157. 